\title{
Pelatihan Literasi Media Digital bagi Murid-Murid Armidale English College (AEC) di Soreang Kabupaten Bandung Selatan
}

\author{
Ditha Prasanti ${ }^{1 *}$, Sri Seti Indriani ${ }^{1}$ \\ ${ }^{1}$ Fakultas Ilmu Komunikasi, Universitas Padjadjaran. Jalan Raya Jatinangor Sumedang KM.21 \\ Bandung, Indonesia \\ * Corresponding Author. Email: Email: dithaprasanti@gmail.com \\ Received: 19 August 2017; Revised: 8 November 2017; Accepted: 4 December 2017
}

Abstrak

Kegiatan ini memiliki tujuan dapat menghasilkan luaran yaitu: (1) Memberikan pengetahuan dan wawasan yang konkret mengenai pelatihan literasi media digital; (2) Memberikan kemampuan dasar mengenai pelatihan literasi media digital bagi murid-murid AEC di Soreang Kab.Bandung Selatan. Metode pelaksanaan PKM yang dilakukan dalam kegiatan penyuluhan ini adalah metode ceramah; metode diskusi; dan metode kaji tindak. Kesimpulan dari pelatihan literasi media digital ini adalah: (1) Sebagai tolak ukur seberapa jauh murid-murid AEC mengetahui literasi media digital; (2) Meningkatkan kesadaran mereka akan pentingnya melek media digital berkaitan dengan segala informasi yang dianggap penting dalam media untuk generasi digital berikutnya; (3) Meningkatkan kemampuan dasar murid AEC tentang literasi media digital.

Kata Kunci: pelatihan, literasi, media, digital, murid AEC

\section{Digital Media Literacy Training for Students Armidale English College $(A E C)$ in Soreang, District of South Bandung}

\begin{abstract}
The activity is aimed at producing the following outputs: (1) Providing concrete knowledge and insight into digital media literacy training; (2) Providing basic skills on digital media literacy training for AEC students in Soreang Kab.Bandung Selatan. The method of PKM implementation conducted in this extension activity is the lecture method; Method of discussion; and action research method. The conclusions of this digital media literacy training are: (1) As a measure of how far AEC students know the digital media literacy; (2) Increasing their awareness of the importance of digital media literacy in relation to any information deemed important in the media for the next digital generation; (3) Improving the basic skills of AEC students about digital media literacy.
\end{abstract}

Keywords: training, literacy, media, digital, AEC students

How to Cite: Prasanti, D., \& Indriani, S. (2017). Pelatihan literasi media digital bagi murid-murid armidale english college (AEC) di Soreang Kabupaten Bandung Selatan. JPPM (Jurnal Pendidikan dan Pemberdayaan Masyarakat), 4(2), 157-165. doi:http://dx.doi.org/10.21831/jppm.v4i2.15364

Permalink/DOI: http://dx.doi.org/10.21831/jppm.v4i2.15364 


\section{Jurnal Pendidikan dan Pemberdayaan Masyarakat, 4 (2), November 2017 - 158}

Ditha Prasanti, Sri Seti Indriani

\section{PENDAHULUAN}

Pada saat ini, masyarakat di Indonesia telah memasuki era perkembangan teknologi yang modern, ditandai dengan padatnya informasi, kuatnya komunikasi, dan keterbukaan informasi. Masyarakat informasi yang diiringi oleh kemajuan teknologi ini berkembang pesat dalam kehidupan manusia. Media digital memberikan peluang dalam proses transfer informasi dan data sehingga dapat kemudian diakses lebih cepat dengan jangkauan yang luas. Oleh karena itu, untuk menghadapi era ini, sebagai generasi penerus Indonesia, sebaiknya kita harus mengimbangi dengan kemampuan literasi media digital yang baik.

Kegiatan literasi selama ini identik dengan aktivitas membaca dan menulis. Namun, Deklarasi Praha pada tahun 2003 menyebutkan bahwa literasi juga mencakup bagaimana seseorang berkomunikasi dalam masyarakat. Literasi juga bermakna praktik dan hubungan sosial yang terkait dengan pengetahuan, bahasa, dan budaya (UNESCO, 1990).

Deklarasi UNESCO juga menyebutkan bahwa literasi informasi terkait pula dengan kemampuan untuk mengidentifikasi, menentukan, menemukan, mengevaluasi, menciptakan secara efektif dan terorganisasi, menggunakan dan mengomunikasikan informasi untuk mengatasi berbagai persoalan. Kemampuan-kemampuan itu perlu dimiliki tiap individu sebagai syarat untuk berpartisipasi dalam masyarakat informasi, dan itu bagian dari hak dasar manusia menyangkut pembelajaran sepanjang hayat (Wiedarti et al., 2016).

Penulis merasakan pentingnya melakukan pelatihan literasi media digital bagi murid AEC karena melihat potensi dan semangat belajar murid-murid AEC yang baik, tentu harus diimbangi dengan kemampuan literasi media digital. Apalagi mengingat lokasi AEC yang berada di Soreang, sebagai ibukota kabupaten Bandung, selayaknya juga diimbangi dengan kemampuan melek literasi media digital.

Pengetahuan akan pentingnya kompetensi literasi media digital selayaknya diketahui oleh masyarakat luas, khususnya generasi muda yang secara langsung berhadapan dengan aspek teknologi digital. Oleh karena itu, pengetahuan tentang literasi media digital sangat diperlukan bagi generasi muda, dalam hal ini pada muridmurid dalam sebuah sekolah bahasa Inggris yang terletak di Soreang, Kabupaten Bandung Selatan. Sekolah tersebut bernama Armidale English College (AEC). AEC merupakan satu-satunya sekolah lembaga Bahasa Inggris yang terkenal dengan kuantitas dan kualitas muridnya yang sangat baik di Soreang.

Berdasarkan latar belakang masalah, maka penulis melakukan kegiatan Pengabdian Kepada Masyarakat (PKM) mengenai Pelatihan Literasi Media Digital bagi MuridMurid Armidale English College (AEC) di Soreang, Kabupaten Bandung Selatan.

Mengingat pentingnya pengetahuan tentang peran literasi media digital di kalangan anak muda, saat ini, mereka harus memahami dan menyadari bahwa mereka hidup di era digital. Hal inilah yang menjadi alasan penting bahwa generasi muda harus memiliki literasi media digital yang baik.

Literasi media adalah kemampuan seseorang dalam menggunakan berbagai media untuk mengakses serta menghasilkan informasi dalam kehidupan sehari-hari. Adapun jenis media yang biasa dikonsumsi berupa televisi, film, radio, musik terekam, surat kabar, dan majalah.

Selain media tersebut, saat ini yang dinamakan media digital adalah dengan kehadiran internet. Bahkan, saat ini melalui telepon seluler pun dapat diakses. Istilah literasi digital mulai populer sekitar tahun 2005 (Davis \& Shaw, 2011), literasi digital bermakna kemampuan untuk berhubungan dengan informasi hipertekstual dalam arti bacaan tak berurut berbantuan komputer. Istilah literasi digital pernah digunakan tahun 1980-an (Davis \& Shaw, 2011), secara umum bermakna kemampuan untuk berhubungan dengan informasi hipertekstual dalam arti membaca non-sekuensial atau nonurutan berbantuan komputer (Bawden, 2001).

Literasi media adalah keterampilan yang kita dapat begitu saja, tetapi seperti semua keterampilan, hal ini dapat ditingkat- 
kan. Jika kita mempertimbangkan betapa pentingnya media massa dalam menciptakan dan mempertahankan budaya yang akan membantu menentukan hidup kita, ini merupakan keterampilan yang harus ditingkatkan (Kurniawati \& Baroroh, 2016).

Gilster (2007) memperluas konsep literasi digital sebagai kemampuan memahami dan menggunakan informasi dari berbagai sumber digital, dengan kata lain kemampuan untuk membaca, menulis, dan berhubungan dengan informasi dengan menggunakan teknologi dan format yang ada pada masanya.

IFLA ALP Workshop (2006) menyebutkan bagian dari literasi informasi adalah literasi digital, didefinisikan sebagai kemampuan memahami dan menggunakan informasi dalam berbagai format dari sejumlah besar sumber daya tatkala sumber daya tersebut disajikan melalui komputer. Dengan perkembangan internet, maka pemakai tidak tahu atau tidak mempedulikan dari mana asalnya informasi, yang penting mereka dapat mengaksesnya.

Istilah media mencakup semua media komunikasi, kadang-kadang digunakan istilah media massa untuk mencapai audisi hangat besar seperti televisi siaran dan bayar, radio, film, surat kabar dan majalah. Literasi media mencakup semuanya dari memiliki pengetahuan yang diperlukan untuk menggunakan teknologi media lama dan baru sampai dengan memiliki hubungan kritis ke konten media.

Literasi media terdiri dari dua kata, yakni literasi dan media. Secara sederhana, literasi dapat diartikan sebagai kemampuan membaca dan menulis atau dengan kata lain melek media aksara sedangkan media dapat diartikan sebagai suatu perantara baik dalam wujud benda, manusia, peristiwa, maka literasi media dapat diartikan sebagai kemampuan untuk mencari, mempelajari, dan memanfaatkan berbagai sumber media dalam berbagai bentuk (Kurniawati \& Baroroh, 2016).

Pengabdian Kepada Masyarakat (PKM) dengan mengadakan Pelatihan Literasi Media Digital bagi Murid Armidale English College (AEC) ini tentunya diharapkan dapat menghasilkan luaran sebagai berikut: (1)
Memberikan pengetahuan dan wawasan yang konkret mengenai dunia digital dan perkembangannya saat ini kepada para murid AEC; (2) Memberikan pengetahuan dan wawasan menyeluruh mengenai konsepkonsep Literasi Media Digital kepada para murid AEC; (3) Mendorong murid untuk secara aktif dan kreatif merancang sebuah karya digital yang merupakan hasil dari sebuah pelatihan literasi media digital; (4) Mendorong para murid AEC agar rajin terlibat dalam pelaksanaan kegiatan atau pelatihan yang berkaitan dengan literasi media digital.

\section{METODE}

Kegiatan pelatihan Literasi Media Digital yang telah dilakukan ini, dengan mempertimbangkan materi pelatihan, siswa Armidale English College (AEC) sebagai peserta pelatihan, masalah yang berkembang dan lingkungan yang mendukung, dalam pelaksanaannya juga telah menggunakan beberapa metode sebagai berikut:

Pertama, metode ceramah, dengan memberikan wawasan umum kepada siswa mengenai pelatihan literasi media digital dan perkembangannya dewasa ini. Begitupun halnya dalam kegiatan PKM ini, metode ceramah digunakan ketika tim PKM menyampaikan materi kepada para peserta, dalam hal ini adalah murid-murid AEC. Dengan menggunakan metode ceramah ini, peserta menjadi tahu berbagai hal tentang literasi media digital yang belum diketahui.

Kedua, Metode diskusi kelompok, di mana setelah selesai melakukan simulasi dan diskusi siswa diberikan kesempatan untuk bertanya, mengutarakan pendapat, dan berdialog. Dalam bagian ini, peserta PKM yaitu para murid AEC sangat aktif melakukan diskusi kelompok. Selain aktif bertanya, mereka juga aktif dalam kegiatan simulasi dalam kelompoknya. Para murid terlihat antusias melalui metode diskusi kelompok ini. Apalagi ketika setiap kelompok menunjukkan hasil diskusinya kepada peserta lainnya. Oleh karena itu, metode diskusi kelompok juga penting dilakukan.

Kegiatan diskusi ini juga disaksikan oleh pimpinan dari lembaga AEC yang menyatakan pentingnya kegiatan tersebut 


\section{Jurnal Pendidikan dan Pemberdayaan Masyarakat, 4 (2), November 2017 - 160}

Ditha Prasanti, Sri Seti Indriani

karena secara tidak langsung memberikan ilmu yang sangat bermanfaat di era ini, yaitu mengenai literasi media digital.

Para peserta pun cepat tanggap dalam memahami materi yang disampaikan. Dalam metode diskusi ini, penulis melihat para peserta juga mendiskusikan berbagai fenomena yang mereka alami terkait literasi media digital. Ternyata selama ini, mereka belum memahami penggunaan media digital yang baik dan benar. Dalam diskusi ini, para peserta juga saling menanggapi peristiwa yang dialami masing-masing.

Ketiga, metode kaji tindak, di mana siswa membentuk kelompok dan kemudian diberikan kesempatan untuk merancang sebuah karya digital dalam kegiatan atau pertunjukan yang kreatif sesuai dengan tema-tema tertentu, sebagai hasil pembelajaran dari kegiatan pelatihan ini. Dalam metode ini, tim PKM memberikan kesempatan kepada para peserta untuk mengkaji atau merancang karya digital kreatif dengan melakukan proses literasi media digital yang telah dipelajari. Hal ini bertujuan sebagai salah satu praktek dari teori yang telah dipelajari. Metode kaji tindak ini juga penting dilakukan agar para peserta mampu menerapkan dalam aktivitasnya mengenai literasi media digital yang baik dan benar.

Metode kaji tindak ini juga sangat bermanfaat dilakukan karena relevan dengan kegiatan ektrakurikuler yang diselenggarakan AEC, yaitu adanya pameran dari karya murid-murid. Oleh karena itu, pimpinan dari lembaga AEC inipun mendukung terselenggaranya kegiatan PKM ini. Kegiatan PKM ini diikuti oleh 30 orang peserta yang terdiri dari murid-murid Armidale English College (AEC) di Soreang.

\section{HASIL DAN PEMBAHASAN}

\section{Hasil yang Dicapai}

Armidale English College (AEC)

Kegiatan Pengabdian Kepada Masyarakat (PKM) ini dilakukan pada sebuah sekolah bahasa Inggris yang terletak di Soreang Bandung selatan, bernama Armidale English College (AEC).

AEC adalah sebuah lembaga sekolah bahasa Inggris yang mengusung visi "to build
Indonesia Anew" atau "Membangun Indonesia baru", yang dimaksud dengan Indonesia baru adalah masyarakat bangsa Indonesia yang diharapkan memiliki nilainilai budaya kejujuran, kedisiplinan dan loyalitas, atau dengan kata lain membangun karakter pribadi bangsa 'satria' atau 'galantry'.

AEC telah berjalan hampir 22 tahun lamanya, murid-murid AEC mengakui bahwa AEC merupakan rumah kedua mereka, karena mereka merasa bahwa AEC telah menjadi bagian dari hidupya dan keluarga keduanya karena banyaknya kegiatan yang dilakukan AEC sehingga kurang lebih memaksakan murid untuk aktif dan bahkan setiap hari para murid datang ke AEC setelah jam sekolah.

Berdasarkan fakta tersebut, AEC menjadi sebuah komunitas tersendiri dimana terjalin rasa bangga yang sangat mendalam diantara murid murid AEC.

\section{Pemaparan Materi Pelatihan}

Dalam rangka melakukan kegiatan pelatihan literasi media digital ini, sekolah bahasa Inggris AEC memfokuskan pada murid-murid tingkat intermediate. Kelas tingkat intermediate ini merupakan muridmurid yang memiliki jenjang umur sekitar 15-20 tahun. Pada umur tersebut akses mereka terhadap media sangat besar, sehingga mereka harus memiliki pengetahuan mengenai literasi media digital.

Materi yang diberikan pada muridmurid tersebut adalah istilah-istilah yang berhubungan dengan media digital, termaksud segala upaya dalam memilih sebuah informasi melalui beragam media digital, yang dijelaskan dalam sesi diskusi untuk berbagi pengalaman ketika menggunakan media digital.

Pada Gambar 1. penulis memberikan pelatihan literasi media digital dengan menyampaikan materi singkat tentang pemahaman media digital itu sendiri. Dalam bagian ini, metode ceramah yang dilakukan penulis bisa dikatakan efektif karena diselingi juga dengan pemutaran video tentang contoh-contoh dari literasi media digital. 


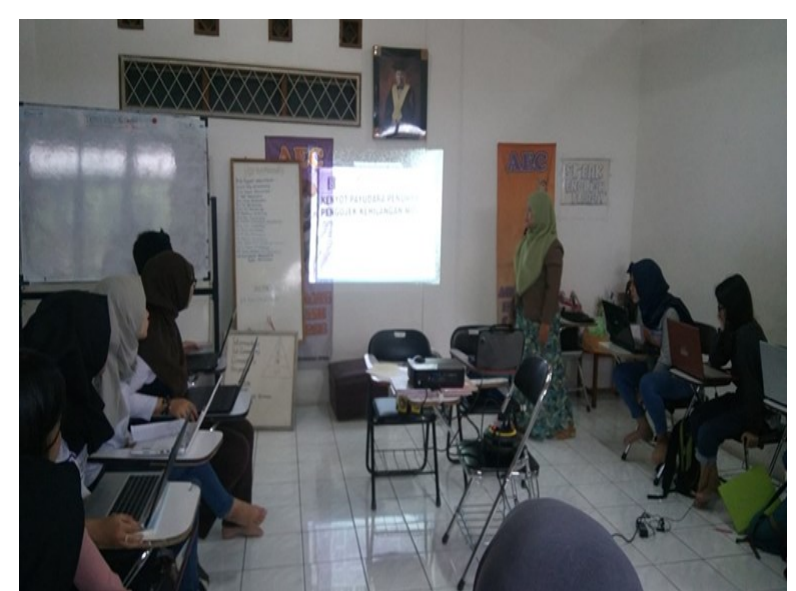

Gambar 1. Proses Pelatihan Literasi Media

Digital bagi Murid AEC di Soreang,

Kab.Bandung diikuti oleh para peserta dengan penuh antusias

Media digital termasuk salah satu gadget dalam media baru, dalam buku Komunikasi dan Komodifikasi dijelaskan definisi media baru (Dennis McQuail, 2000 dalam Ibrahim, Akhmad, \& Wallach (2014) terdapat empat kategori utama yaitu; (1) media komunikasi interpersonal seperti email; (2) media permainan interaktif seperti game; (3) media pencarian informasi seperti mesin pencarian di Net; (4) media partisipatoris, seperti ruang chat di Net.

Tim Pengabdian Kegiatan Masyarakat (PKM) inipun memberikan bentuk pelatihan literasi media digital kepada para murid AEC secara aktif dan menarik, dengan melibatkan partisipasi langsung peserta melalui metode diskusi dan simulasi. Penulis mengajak para peserta berpikir agar dapat membedakan literasi media, literasi teknologi, dan literasi visual. Materi utama yang perlu diberikan adalah mengenai pemahaman fungsi media digital sendiri.

Pemahaman fungsi media digital ini terkait dengan tingkat Literasi Media (Individual Competence) terdiri dari Use Skills, Critical Understanding, Communicative Abilities. Kurniawati \& Baroroh (2016) dalam sebuah artikelnya yang diterbitkan di Jurnal Komunikator Vol.8 No.2 November 2016, menyebutkan tentang tingkat kemampuan literasi media tersebut dijelaskan pula dalam ilustrasi berikut ini.
Dalam mengukur tingkat kemampuan literasi media,terbagi kedalam tiga kategori yaitu:

\section{Use Skills}

Use Skills merupakan kemampuan untuk mengakses dan mengoperasikan media. Use skill mencakup beberapa kriteria, yaitu: (1) Kemampuan menggunakan media (Media Skills); (2) Kemampuan menggunakan media secara aktif (balanced and active use of media); (3) Kemampuan menggunakan dan pemanfaatan media secara tinggi (advanced media use);

\section{Critical Understanding}

Critical understanding merupakan kemampuan untuk menganalisis dan mengevaluasi konten media secara komprehensif. Kriteria critical understanding ini meliputi: (1) Kemampuan memahami konten dan fungsi media (understanding media content and its functioning); (2) Memiliki pengetahuan tentang media dan regulasi media (knowledge about media and media regulation); (3) Perilaku pengguna dalam menggunakan media (user behavior)

\section{Communicative Abilities}

Communicative Abilities yaitu kemampuan komunikasi dan partisipasi melalui media. Communicative abilities ini mencakup kemampuan untuk membangun relasi sosial serta berpatisipasi dalam lingkungan masyarakat melalui media. Selain itu, communicative abilities ini juga mencakup kemampuan dalam membuat dan memproduksi konten media (Kurniawati \& Baroroh, 2016).

Dalam Gambar 2, terlihat sebuah teknik komunikasi persuasif yang dilakukan penulis dalam mengajak para peserta pelatihan untuk meningkatkan literasi media digital. Penulis juga mengajak para peserta berdiskusi tentang hal-hal yang terjadi jika terpaan media memberikan beragam informasi kepada masyarakat tanpa diimbangi dengan literasi media itu sendiri.

Ketika materi tersebut disampaikan, para peserta pun sangat aktif memberikan pendapatnya tentang pengalamannya berkaitan dengan media digital ini. Apalagi 


\section{Jurnal Pendidikan dan Pemberdayaan Masyarakat, 4 (2), November 2017 - 162}

Ditha Prasanti, Sri Seti Indriani

kalangan remaja saat ini sebagai pengguna aktif dari media digital tentu merasakan langsung efek dari media tersebut. Berdasarkan pendapat dari para peserta pelatihan, penulis pun dapat melihat tingkat kemampuan literasi media digital yang dimiliki peserta. Peserta pun menyadari bahwa tujuan lain dari literasi media digital ini adalah untuk meminimalisir munculnya beragam informasi yang bersifat hoax.

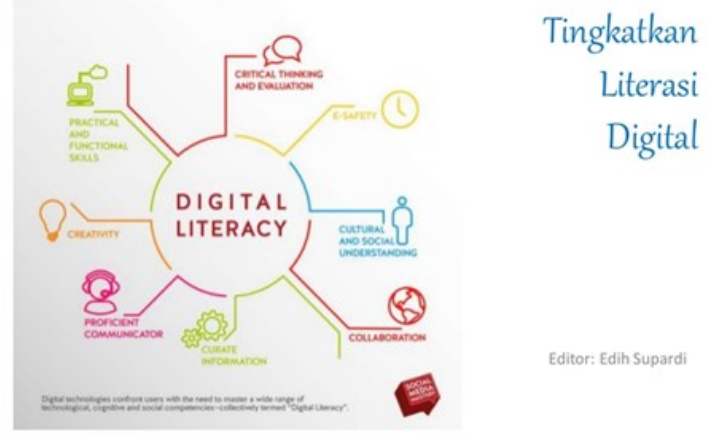

Gambar 2. Materi Pelatihan Literasi Media

Digital tentang tingkat Kemampuan Literasi Media Digital

Selain itu, jika berbasis pada literasi komputer dan informasi, Bawden (2001) menyusun konsep literasi digital. Bawden (2001) menyebutkan bahwa digital literasi menyangkut beberapa aspek berikut ini: (1) Perakitan pengetahuan yaitu kemampuan membangun informasi dari berbagai sumber yang terpercaya; (2) Kemampuan menyajikan informasi termasuk di dalamnya berpikir kritis dalam memahami informasi dengan kewaspadaan terhadap validitas dan kelengkapan sumber dari internet; (3) Kemampuan membaca dan memahami materi informasi yang tidak berurutan (nonsequential) dan dinamis; (4) Kesadaran tentang arti penting media konvensional dan menghubungkannya dengan media berjaringan (internet); (5) Kedadaran terhadap akses jaringan orang yang dapat digunakan sebagai sumber rujukan dan pertolongan; (6) Penggunaan saringan terhadap informasi yang datang; (7) Merasa nyaman dan memiliki akses untuk mengkomunikasikan dan mempublikasikan informasi

Ketika tim PKM memaparkan konsep di atas, peserta tidak terlihat antusias karena isi konsepnya kurang mengena dengan kegiatan sehari-hari yang mereka alami. Tetapi ketika tim PKM menyampaikan konsep dari Bawden (2001), para peserta langsung cepat tanggap menyampaikan pengalamannya mengenai literasi media digital yang mereka alami, khususnya dari media sosial.

Jika menilik pendapat Bawden (2001) tersebut maka digital literasi lebih banyak dikaitkan dengan keterampilan teknis mengakses, merangkai, memahami dan menyebarluaskan informasi.

Pendapat berbeda disampaikan oleh Buckingham (2007) yang mengikuti pola komponen-komponen literasi media yang sebelumnya telah berkembang luas. Ia menyatakan bahwa digital literasi juga berkaitan dengan empat komponen penting yaitu: representasi, bahasa, produksi dan khalayak. Satu per satu akan dibahas berikut ini (Buckingham, 2007, pp. 47-49).

Representasi: sebagaimana media lain, media digital merepresentasikan dunia bukan semata-mata merefleksikan dunia itu sendiri. Beberapa bagian dalam media digital adalah hasil intrepretasi dan seleksi atas kenyataan.

Bahasa: individu tidak saja dituntut mampu berbahasa namun juga memahami aneka kode dan konvensi pada berbagai genre konten. Hal ini membutuhkan kemampuan untuk memahami berbagai retorika fungsi bahasa seperti persuasi, eufimisme, hiperbola, dan lain sebagainya.

Produksi: literasi juga berkaitan dengan pemahaman mengenai siapa yang berkomunikasi kepada siapa dan mengapa. Hal ini berkaitan dengan motif komunikasi sehingga khalayak dapat memahami 'keamanan' konten.

Khalayak: hal ini terkait dengan posisi khalayak yaitu pemahaman tentang bagaimana media menempatkan, menarget dan merespon khalayak termasuk di dalamnya cara-cara media digital mendapatkan informasi dari khalayak berkaitan dengan isu privasi dan keamanan pengguna.

Ketika tim PKM memaparkan mengenai pentingnya literasi media digital, ada berbagai pendapat yang disampaikan oleh peserta, berkaitan dengan konsep dari Buckingham (2007) yang mengatakan 


\section{Jurnal Pendidikan dan Pemberdayaan Masyarakat, 4 (2), November 2017 - 163}

Ditha Prasanti, Sri Seti Indriani

adanya komponen dalam literasi digital, yaitu representasi, bahasa, produksi, dan khalayak.

Sebagian peserta menyampaikan bahwa komponen bahasa dan khalayak inilah yang sangat menonjol dalam literasi media digital, karena tanpa disadari penggunaan bahasa dalam media digital ini juga mempengaruhi bahasa yang mereka gunakan dalam kehidupan sehari-hari.

Setelah sesi diskusi selesai, penulis juga mengajak para peserta untuk membuat sebuah karya digital yang kreatif sebagai hasil pembelajaran dari pelatihan tersebut.

Dalam pembuatan karya digital tersebut, para peserta pelatihan diberikan waktu selama satu bulan. Karya digital ini dibuat dari, oleh, dan untuk para murid AEC. Mereka didorong untuk membuat sebuah karya digital yang berisi 'pengetahuan' dan 'informasi' mengenai apa yang telah mereka dapat dari AEC, setelah belajar lama di AEC yakni sekitar 7 tahun lamanya. Pengetahuan dan informasi tersebut kemudian dijadikan sebuah cerita yang diunggah pada media digital, dengan memadukan informasi yang relevan dari media digital tersebut.

Sebagai ajang pembelajaran hasil pelatihan ini, penulis pun telah berkoordinasi dengan pimpinan AEC agar karya digital yang dibuat inipun kelak ditampilkan dalam sebuah pertunjukan di AEC.

Peserta pelatihan ini diharapkan dapat memahami tentang media digital mulai dari use skills, critical understanding, dan communicative abilities. Jika peserta pelatihan memahami pentingnya literasi media digital ini, tentu dapat terlihat dalam pembuatan karya digital tersebut.

Penulis sebagai tim pemateri dalam kegiatan pelatihan ini telah memberikan materi dasar yang mudah dipahami dan bersifat menuntun para peserta dalam memiliki literasi media digital. Hal ini karena para peserta tentu membutuhkan proses sehingga sampai pada tahap perilaku/ behavioral.

\section{Monitoring dan Evaluasi Program}

Kegiatan PKM yang dilakukan penulis berjalan dengan lancar. Setelah pemberian materi, diskusi, dan simulasi selesai, maka penulis tetap melakukan kegiatan monitor- ing dan evaluasi program. Para peserta juga diberikan pemahaman tentang pentingnya gerakan literasi media sebagai bahan evaluasi dalam proses pembuatan karya digital, dari, oleh, dan untuk murid Armidale English College (AEC).

Setelah kegiatan PKM ini dilaksanakan, penulis melihat bahwa tujuan dari kegiatan PKM ini telah terlaksana yaitu memberikan informasi mengenai literasi media digital kepada murid-murid AEC. Pada kenyataannya, murid-murid AEC tersebut belum pernah mendapatkan informasi yang sama seperti disampaikan oleh tim PKM dalam kegiatan PKM tersebut.

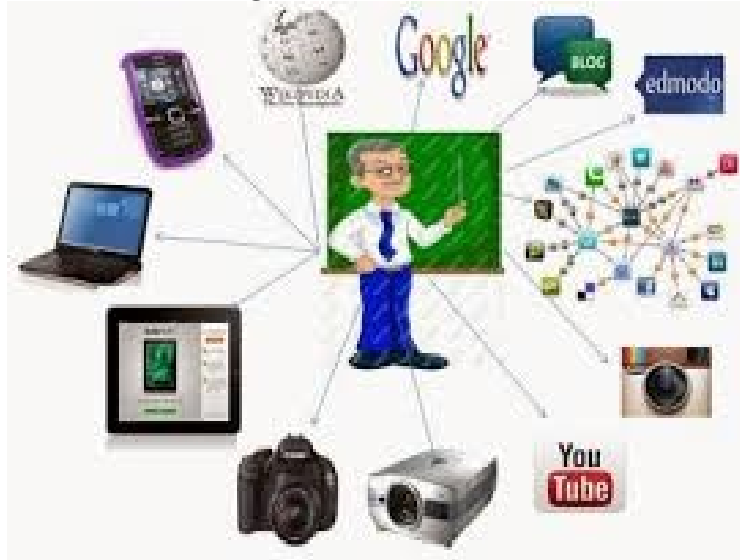

Gambar 3. Highlight Pentingnya Literasi ditengah Keberagaman Media Digital

Selanjutnya, Herlina S (2015) dalam artikelnya yang berjudul "Membangun Karakter Bangsa Melalui Literasi Digital” juga mengatakan bahwa hal penting lain, pembelajaran dengan menggunakan media digital juga melibatkan pembelajaran mengenai nilai-nilai universal yang harus ditaati setiap penguna seperti kebebasan berekspresi, privasi, keberagaman budaya, hak intelektual dsb. Maka siswa akan memahami bahwa media digital seperti sekeping mata uang: kebebasan informasi di satu sisi dan pelanggaran privasi di sisi lain.

Kedua sisi itu harus dipahami dan digunakan dalam jangkauan tertentu sehingga tidak merugikan diri sendiri dan pihak lain. Selain melalui pendidikan formal, pembelajaran literasi digital juga dapat dikerjakan dalam pendidikan masyarakat melalui kelompok pengajian, PKK, Karang Taruna, komunitas hobi dsb. Literasi media digital merupakan alat penting untuk mengatasi 


\section{Jurnal Pendidikan dan Pemberdayaan Masyarakat, 4 (2), November 2017 - 164}

Ditha Prasanti, Sri Seti Indriani

berbagai persoalan sosial seperti pornografi dan pornoaksi, penggunaan alkohol, rokok dan obat terlarang, kegemukan dan kelainan makan, penganiayaan dan kekerasan, identitas gender dan seksualitas, rasialisme, diskriminasi, penindasan dan ketrampilan hidup (Herlina S, 2015).

Literasi digital membuat masyarakat dapat mengakses, memilah dan memahami berbagai jenis informasi yang dapat digunakan untuk meningkatkan kualitas hidup seperti kesehatan dan pengasuhan anak, keluarga. Selain itu mereka dapat berpartisipasi dalam kehidupan bermasyarakat, bernegara dan berpolitik dengan menyampaikan aspirasinya di kanal-kanal tertentu (Herlina S, 2015).

Melalui media digital, masyarakat dapat menyuarakan perspektif dan opininya demi keadilan tanpa merugikan pihak lain. Tujuan ekonomi juga dapat dicapai melalui literasi digital melalui pemahaman mengenai transaksi online. Pendek kata, literasi digital membuat seseorang dapat mengawasandi lingkungannya dengan baik. Sehingga ia dapat berpartisipasi dalam kehidupan sosial dengan lebih baik. Maka dari itu, literasi digital perlu dikembangkan di sekolah dan masyarakat sebagai bagian dari pembelajaran sepanjang hayat (Herlina S, 2015).

Data tersebut memperkuat pentingnya dilakukan kegiatan PKM ini. Oleh karena itu, untuk tetap menjaga kontinuitas dari program PKM ini, penulis melakukan kegiatan monitoring. Monitoring kegiatan Pelatihan Literasi Media Digital bagi murid-murid AEC ini telah dilakukan satu bulan setelah kegiatan pelatihan dilakukan, yaitu dengan cara: (1) Mendatangi sekelompok peserta pelatihan untuk mendapatkan feedback dari materi yang telah disampaikan; (2) Mendatangi kantor AEC, mewawancarai Pimpinan Sekolah AEC, Endang Supeni, untuk mengetahui adanya tingkat partisipasi dan peningkatan kompetensi dari peserta pelatihan tersebut sebagai hasil dari pelatihan yang dilakukan; (3) Evaluasi kegiatan pelatihan dilakukan pada akhir kegiatan, yaitu setelah pelaksanaan monitoring dengan cara; (a) Melihat animo atau antusiasme peserta mengikuti penyuluhan yang dapat dilihat dari kehadiran jumlah peserta, keaktifan peserta dalam berpendapat dan bertanya, serta antusiasme dan ekspresi mereka selama mengikuti pelatihan; (b) Membandingkan sikap peserta pelatihan sebelum mendapatkan dan setelah mendapatkan materi; (c) Mengapresiasi karya digital yang telah dibuat oleh para peserta dalam memilih informasi yang aktual dan faktual dalam media digital.

\section{SIMPULAN}

Hasil dari pengabdian pada masyarakat ini terlihat bahwa: (1) Para murid AEC menyadari pentingnya memiliki pengetahuan tentang literasi media digital, bahwa mereka memiliki tanggung jawab pada masa sekarang dan masa depan, khususnya dalam penyebaran informasi melalui media digital; (2) Para murid AEC secara aktif dan kreatif merancang sebuah karya digital yang memiliki nilai jual mengenai AEC. Mereka didorong untuk membuat sebuah 'informasi' mengenai apa yang telah mereka dapat dari AEC setelah belajar lama di AEC yakni sekitar 7 tahun lamanya, pengetahuan dan informasi tersebut kemudian dijadikan sebuah cerita yang diunggah pada media digital, dengan memadukan informasi yang relevan dari media digital tersebut. Project ini telah dibuat dalam kurun waktu 1 bulan dan telah dievaluasi secara bersama-sama oleh tim PKM dan Pimpinan AEC; (3) Para murid AEC tertantang untuk terlibat dalam literasi media digital karena akan membuka pola pikir dan pengetahuan mereka; (4) Pelatihan ini memberikan motivasi dan tolak ukur para siswa AEC tentang kompetensi literasi media digital yang selayaknya dimiliki sejak saat ini.

Adapun saran yang ingin diberikan sebagai berikut: (1) Perlunya pelatihan literasi media digital lainnya yang terus berkelanjutan agar memotivasi para murid AEC tetap konsisten dalam mengatasi dampak dari kemajuan teknologi dan informasi yang sangat cepat; (2) Untuk mengoptimalkan literasi media digital ini dianjurkan agar setiap sekolah memfasilitasi murid-muridnya dengan segala hal yang berhubungan dengan media digital, sehingga murid-murid akan memiliki pengetahuan yang baik dan 


\section{Jurnal Pendidikan dan Pemberdayaan Masyarakat, 4 (2), November 2017 - 165}

Ditha Prasanti, Sri Seti Indriani

benar dalam menyikapi perkembangan media digital selanjutnya.

\section{UCAPAN TERIMAKASIH}

Artikel ini merupakan karya ilmiah yang ditulis berdasarkan hasil kegiatan Pengabdian Kepada Masyarakat (PKM) skema Mandiri Fakultas Ilmu Komunikasi Universitas Padjadjaran, yang telah dilakukan di AEC, Soreang, Kab.Bandung Selatan. Oleh karena itu, penulis ingin mengucapkan terimakasih atas izin dan dukungannya kepada: (1) Dr. Dadang Rahmat Hidayat, S.H, S.Sos, M.Si, Dekan Fakultas Ilmu Komunikasi Universitas Padjadjaran; (2) Dr. Trie Damayanti, M.Si, Manajer Riset, Inovasi, dan Kerjasama Fakultas Ilmu Komunikasi Universitas Padjadjaran; (3) Dr. Purwanti Hadisiwi, M.Exced, Ketua Program Studi Ilmu Komunikasi Fikom Universitas Padjadjaran; (4) Dr. Aceng Abdullah, M.Si, Ketua Program Studi Televisi dan Film Fikom Universitas Padjadjaran; (5) Pimpinan dan Staff Armidale English College (AEC) di Soreang, Kab.Bandung Selatan

\section{DAFTAR PUSTAKA}

Bawden, D. (2001). Information and digital literacies: A review of concepts. Journal of Documentation, 57(2), 218-259. https://doi.org/10.1108/EUMoooooooo 07083

Buckingham, D. (2007). Digital media literacies: Rethinking media education in the age of the internet. Research in Comparative and International Education, 2(1), 43-55. https://doi.org/10.2304/rcie.2007.2.1.43

Davis, C. H., \& Shaw, D. (2011). Introduction to information science and technology. Published for the American Society for Information Science and Technology by Information Today. Retrieved from
http://books.infotoday.com/asist/Intro duction-to-Information-Science-andTechnology.shtml

Gilster, P. (2007). Digital literacy. New York, NY: Wiley Computer.

Herlina S, D. (2015). Membangun karakter bangsa melalui literasi digital. Yogtyakarta. Retrieved from http://staff.uny.ac.id/sites/default/files /pengabdian/dyna-herlina-suwartomsc/membangun-karakter-bangsamelalui-literasi-digital.pdf

Ibrahim, I. S., Akhmad, B. A., \& Wallach, J. (2014). Komunikasi dan komodifikasi: Mengkaji media dan budaya dalam dinamika globalisasi. Jakarta : Yayasan Pustaka Obor Indonesia.

IFLA ALP Woorkshop on Information Literacy and IT, Auckland, New Zealand. (2006). The basic information literacy skills.

Kurniawati, J., \& Baroroh, S. (2016). Literasi media digital mahasiswa Universitas Muhammadiyah Bengkulu. Jurnal Komunikator, 8(2), 51-66. Retrieved from

http://journal.umy.ac.id/index.php/jk $\mathrm{m} /$ article/view/2069

UNESCO. (1990). World declaration on education for all and framework for action to meet basic learning needs. Paris: UNESCO.

Wiedarti, $\quad$ P., Kisyani-Laksono, Retnaningdyah, P., Dewayani, S., Muldian, W., Sufyadi, S., ... Antoro, B. (2016). Desain induk gerakan literasi sekolah. Jakarta: Direktorat Jenderal Pendidikan Dasar dan Menengah Kementerian Pendidikan dan Kebudayaan. Retrieved from https://awan965.files.wordpress.com/2 o17/o9/desain-induk-gerakan-literasisekolah.pdf 